\title{
DIRECT SELECTION RESPONSE OF PROTEIN EFFICIENCY OF EGG PRODUCTION IN SINAI BEDOUIN FOWL
}

\author{
(1) Faculty of Agric. Menoufia Univ. \\ (2) Minst. of Agriculture.
}

M.E. Soltan ${ }^{(1)}$, A.A. Enab ${ }^{(1)}$, G.A. Zanaty ${ }^{(1)}$ and E.A. Morsy ${ }^{(2)}$

Received: Oct. 25, 2018

Accepted: Dec. 2, 2018

ABSTRACT: The present experiment was carried out in the Poultry Farm, Department of Poultry and Fish Production, Faculty of Agriculture, Menoufia University at Shibin ElKom, Egypt. The local strain used was Sinai Bedouin fowl. The experiments lasted for four years, starting from October 2014. The aim of the experiment was to study the response of selection for high protein efficiency (g protein/g egg) of laying Sinai hens.

Protein efficiency for egg production during the first 90 days of production was calculated according to :

1. Protein efficiency (g Protein /g egg) = Protein consumption

(Selected trait)

The average protein efficiencies were $0.770 \pm 0.159,1.001 \pm 0.452$ and $0.670 \pm 0.171$ in the first, second and third generations, respectively. The actual genetic responses to selection for protein efficiency were obtained. The selection responses were -0.081, 0.132 and $-0.528(\mathrm{~g})$ in the first, second and third generations, respectively. The calculated heritability for protein efficiency $g$ protein per $1 \mathrm{~g}$ eggs was 0.12

Key words: Protein efficiency, selection response, Sinai Fowl.

\section{INTRODUCTION}

Seeman et al., (1983) obtained that feed costs of egg production were about $60-65 \%$ for the total cost and Grasenack (1981) found that the reducing the feed intake from $180 \mathrm{~g} / \mathrm{egg}$ to $165 \mathrm{~g} / \mathrm{egg}$ or $160 \mathrm{~g} / \mathrm{egg}$ lead to reduce the total costs by 4 or $5 \%$. But he noticed also that besides the reducing of feed cost the efficiency of nutrient element ingredient was improved. Protein intake and efficiency is one of the highest nutrient ingredient cost.

Another reason for selection for protein efficiency is estimate the genetic vocalic of protein efficiency in order to improve it through the breeding programs. Also estimate the phenotypes and genetic correlation with the correlated traits.

Question tested:

1- The phenotypic and genetic variation for protein efficiency between individuals within the strain will be tested and estimate the heritability of this traits.

2- Estimate the relationship between better protein efficiency and the egg production traits.

3- Estimate the rate of selection response per generation.

The present study was aimed to investigate the possibility of improvement the protein utilization for egg production Sinai Bedouin fowl as one of our local strain. Such local strains which improved to produce high egg production with reducing feed costs.

\section{MATERIALS AND METHODS}

The present experiment was carried out in the Poultry Farm, Department of Poultry and Fish Production, Faculty of Agriculture, Menoufia University at Shibin El-Kom, Egypt. The local strain used was Sinai Bedouin fowl. The 
experiments lasted for four years, starting from October 2004. The aim of the experiment was to study the response of selection for high protein efficiency (g protein/g egg) of laying Sinai hens.

Fig. 1 showed experimental plan during 3 years. A base population consisted of 300 Sinai pullets aged 20 weeks were used to measure individually protein consumption.

A total of 50 hens were chosen at random from the base population as a control line with no significant difference between control and the base line. In each generation $\mathbf{5 0}$ females and $\mathbf{1 7}$ males were chosen at random with aim to keep family size stable as possible in order to minimize the inbreeding effect according to Soltan (1984), and mated randomly with expectations of the full sib mating.

Mating system was applied by collect semen from one sire to three dams. Insemination was done three times a week and two weeks before collecting hatching eggs. The semen used for the insemination was fresh and undiluted.

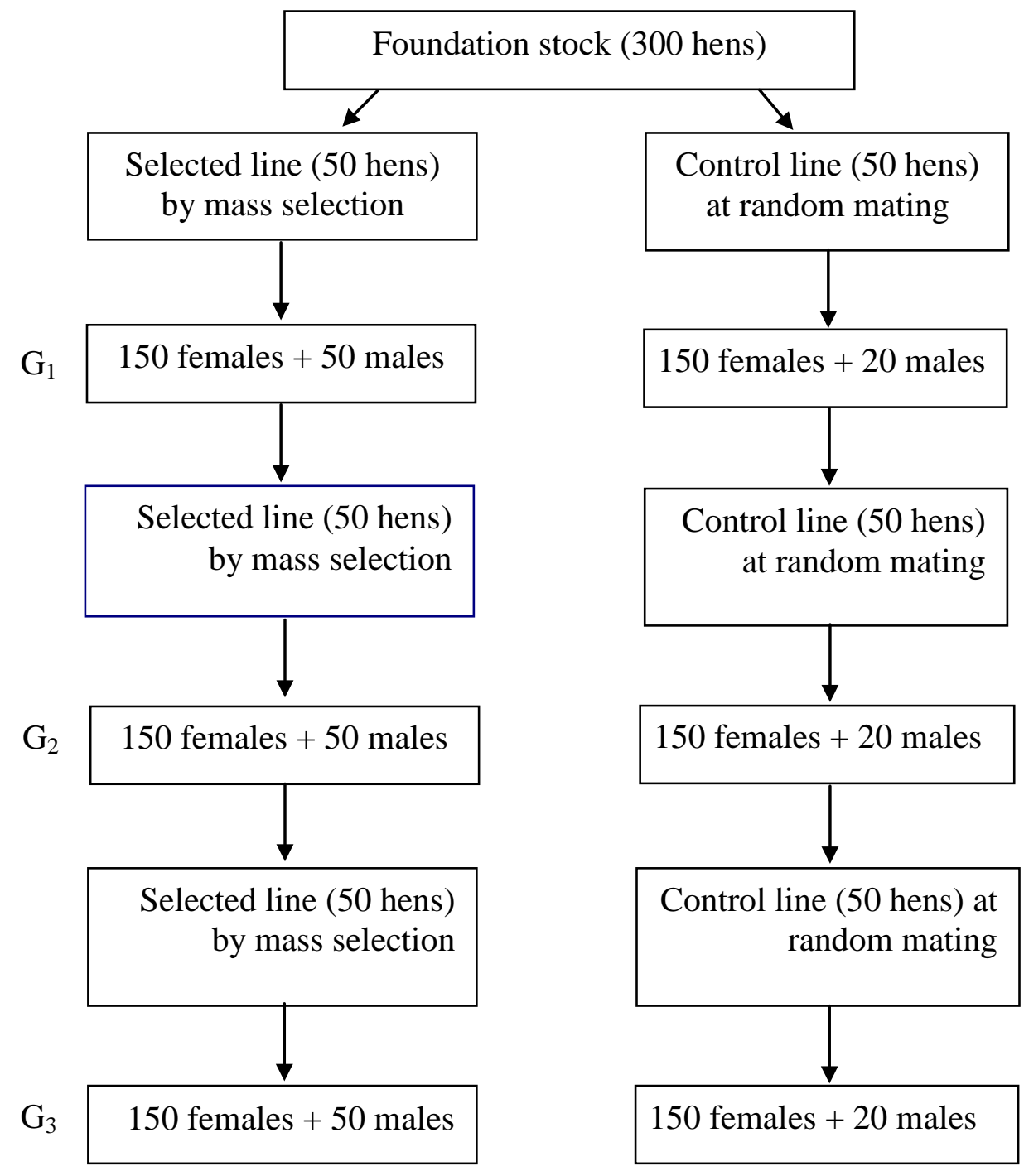

Fig 1 : Experimental plan. 
Chicks were brooded in floor brooder watered continuously and fed ad libitum during brooding period a starter containing $19.43 \%$ crude protein and $2916 \mathrm{ME}$, kcal /kg., then at 16 weeks the diet was changed by a layer containing $17.10 \%$ crude protein and $2760 \mathrm{ME}$, kcal /kg., the compositions of the two diets are given in Table (1).

Pedigreed hatching eggs were collected from each dam through 15 days period and stored in a cold room at $55^{\circ} \mathrm{F}$ and $80-90 \%$ relative humidity. The stored eggs were move to hatching room one night before incubation. After 18 days of incubation the egg were transferred to the hatching compartment. At hatching day chicks were wingbanded and weighted.
Precautions were taken to estimate the actual feed intake per hen using separate individual cages and more over enough distances between hens were provided to avoid mixed ration. Every week individual records were taken for egg production. Eggs were weighed 3 days every week; Saturday, Tuesday and Thursday. Feed intake weights were weighed 3 days weekly $(700 \mathrm{~g} \mathrm{I}$ hen I weekly). In base population, first, second. Residual feed (remainder feed) were weighed every two weeks till the end of the experimental period (90 days). Feed consumption was calculated for each individual hen as the difference between feed intake and feed residual. Precautions were taken to collect residual feed (i.e. the remainder ration). Body weights were weighed again at the finishing of the experiment.

Table (1): Compositions and calculated analysis of the experimental at layer and starter diet.

\begin{tabular}{|l|c|c|}
\hline \multicolumn{1}{|c|}{ Ingredients } & Starter ration & Layer ration \\
\hline Ground yellow corn (8.9\%) & 62.35 & 61.31 \\
Soybean meal(44\%) & 20.25 & 15.02 \\
Gluten yellow(55\%) & 7.89 & 8.01 \\
Wheat bran (11\%) & 5.82 & 5.18 \\
Limestone, ground & 1.80 & 7.85 \\
Di-calcium phosphate & 1.14 & 1.93 \\
Vitamin and mineral premix(1) & 0.31 & 0.30 \\
L.lysine & 0.10 & 0.06 \\
Sodium choloride (salt) & 0.34 & 0.34 \\
\hline Total kg & 100 & 100 \\
\hline Calculated Value: & & \\
Crude protein & 19.43 & 17.10 \\
ME/kg. Kcal diet & 2916 & 2760 \\
C/P ratio & 150 & 161 \\
Calciun,\% & 0.99 & 3.46 \\
Total Phosphorus,\% & 0.53 & 0.68 \\
\hline
\end{tabular}

1: Vitamin and Mineral mixture : at $0.30 \%$ of the diet supplies the following lof the diet :

Vitamin A $1200 \mathrm{IU}$, V.D3 $2500 \mathrm{IU}$, V.E 10mg, VK3 3mg, V.B1 1mg, V.B2 4mg, BIOTIN $0.05 \mathrm{mg}$, Niacin , $40 \mathrm{mg}$, VB6 3mg, VB12 20mg, CHOLINE Choride 400, Mn. 62mg, fe 62mg, Zn 56 mg, CU $5 \mathrm{mg}$ and Se $0.01 \mathrm{mg}$.

Calculated according to NRC (1994). 


\section{Selected trait :}

Protein efficiency for egg production during the first 90 days of production was calculated according to :

1. Protein efficiency $(\mathbf{g}$ protein $/ \mathbf{g}$ egg $)=$ $\frac{\text { Protein consumption }}{\text { Egg mass }}$

(Selected trait)

Estimates of expected mean squares (E.M.S) of unequal number of progenies per sire analysis of variance were obtained according to the following Table (2):

Statistical analysis :

Model (1) Estimation of genetic parameters :

Studied traits were analyzed by general liner model (GLM) using SAS computer program (SAS 2002) as follow model :

$Y_{i j k l}=\mu+S_{i}+D_{i j}+G_{j}+L_{k}+e_{i j k l}$

Where:

$Y_{i j k l m}=$ The individual observation.

$\mu=$ Overall mean

$S_{i}=$ Effect of $i^{\text {th }}$ sire.

$D_{i j}=$ Effect of $j^{\text {th }}$ dam within $i^{\text {th }}$ sire.

$G_{j}=$ Effect of $j^{\text {th }}$ generation, $j=1,2,3$.

$L_{k}=$ Effect of $k^{\text {th }}$ line, $k=1,2$.

$\mathrm{e}_{\mathrm{ijkl}}=$ Error term NID $(0, \sigma 2 \mathrm{e})$.

Where :

$\mathrm{S}=$ total number of sires.

$D=$ total number of dams.

$\mathrm{N}=$ total number of progenies $=\left(\mathrm{nS}_{1}+\right.$ $\left.\mathrm{nS}_{2}+\mathrm{nS}_{3}+\ldots \ldots . ..\right)$.
$K_{1}=$ total number of progenies for dam.

$\mathrm{K}_{2}=$ total number of progenies for sire.

$S S(T)=$ total sum of squares.

SS(S), MSs = sum of squares between sires and mean squares, respectively.

SS(D), $M S_{D}=$ sum of squares between dams and mean squares, respectively.

$\mathrm{SS}_{\mathrm{w}}, \mathrm{MS}_{\mathrm{w}}=$ between full sibs sum of squares and mean squares, respectively.

$\sigma^{2} s=$ Sires component of variance.

$\sigma^{2} D=$ Dams component of variance.

$\sigma^{2} w=$ progeny within mating components of variance.

$$
\mathrm{K}=\frac{1}{\mathrm{~S}-1}\left(\mathrm{~N}-\frac{\Sigma \mathrm{n}_{\mathrm{j}}^{2}}{\mathrm{~N}}\right)
$$

Where :

$\mathrm{N}=$ total number of progenies.

$N_{i}=$ number of progenies for each mating.

The standard error of heritability were estimated according to the formula of Becker (1980).

Heritability :

The heritability was estimated as four times the ratio of dam and sire observational components to total phenotypic variance (summation of dam, sire and residual variance components) $\sigma^{2}{ }_{D}$ is the dam components, $\sigma^{2} s$ is the sire components and $\sigma^{2} e$ the residual component. The heritability estimated as

$$
\begin{aligned}
& h^{2}{ }_{D}=4 \sigma^{2}{ }_{D} /\left(\sigma^{2}{ }_{D}+\sigma^{2}{ }_{S}+\sigma^{2}{ }_{\mathrm{e}}\right) \\
& h^{2}{ }_{\mathrm{s}}=4 \sigma^{2}{ }_{\mathrm{s}} /\left(\sigma^{2}{ }_{\mathrm{D}}+\sigma^{2}{ }_{\mathrm{s}}+\sigma^{2}{ }_{\mathrm{e}}\right)
\end{aligned}
$$

Table (2) : Analysis of variance of nested model.

\begin{tabular}{|l|c|c|c|c|}
\hline \multicolumn{1}{|c|}{$\begin{array}{c}\text { Source of } \\
\text { variation }\end{array}$} & $\begin{array}{c}\text { Degree of } \\
\text { freedom }\end{array}$ & $\begin{array}{c}\text { Sum of } \\
\text { squares }\end{array}$ & $\begin{array}{c}\text { Mean } \\
\text { squares }\end{array}$ & Expected mean squares \\
\hline $\begin{array}{l}\text { Between sires } \\
\text { Between dams } \\
\text { Within sires }\end{array}$ & $\mathrm{S}-1$ & $\mathrm{SS}(\mathrm{S})$ & $\mathrm{Ms}(\mathrm{S})$ & $\sigma^{2} \mathrm{~W}+\mathrm{K}_{1} \sigma^{2} \mathrm{D}+\mathrm{K}_{2} \sigma^{2} \mathrm{~S}$ \\
$\begin{array}{l}\text { Between progeny } \\
\text { within dams }\end{array}$ & $\mathrm{N} . .-\mathrm{D}-1)$ & $\mathrm{SS}(\mathrm{D})$ & $\mathrm{Ms}(\mathrm{D})$ & $\sigma^{2} \mathrm{~W}+\mathrm{K}_{1} \sigma^{2} \mathrm{D}$ \\
Total & $\mathrm{SS}(\mathrm{W})$ & Ms (W) & $\sigma^{2} \mathrm{~W}$ \\
\hline
\end{tabular}




$$
\text { S.E }{ }_{\left(\sigma_{D}^{2}\right)}=\frac{4 \sqrt{\operatorname{var} .\left(\overline{\sigma^{2}}\right)}}{\sigma^{2}{ }_{S}+\sigma^{2}{ }_{D}+\sigma^{2} \mathrm{~W}}
$$

Where:

$$
\begin{gathered}
\operatorname{Var}\left(\sigma_{\mathrm{D}}^{2}\right)=\frac{2}{\left(\mathrm{n}_{1}\right)^{2}}\left[\frac{\left(\mathrm{MS}_{\mathrm{D}}\right)^{2}}{\left(\mathrm{df}_{\mathrm{D}}\right)^{+2}}+\frac{\left(\mathrm{MS}_{\mathrm{W}}\right)^{2}}{\left(\mathrm{df}_{\mathrm{W}}\right)^{+2}}\right] \\
\text { S.E }\left(\mathrm{h}_{\mathrm{S}}{ }_{\mathrm{S}}\right)=\frac{4 \sqrt{\text { var. }\left(\sigma^{2} \mathrm{~S}\right)}}{\sigma^{2}{ }_{\mathrm{S}}+\sigma^{2}{ }_{\mathrm{D}}+\sigma^{2} \mathrm{~W}}
\end{gathered}
$$

Where:

$$
\text { Var. }\left(\sigma^{2} s\right)=\frac{2}{\left(\mathrm{n}_{2}\right)^{2}}\left[\frac{\left(\mathrm{MS}_{5}\right)^{2}}{\left(\mathrm{df}_{5}\right)^{+2}}+\frac{\left(\mathrm{MS}_{\mathrm{D}}\right)^{2}}{\left(\mathrm{df}_{\mathrm{D}}\right)^{+2}}\right]
$$

Where :

$\sigma^{2}{ }_{D}=$ is the dam component of variance.

$\sigma^{2}{ }^{2}=$ is the sire component of variance.

$\sigma^{2}=$ is the error component of variance.

\section{Genetic gain}

Actual genetic gain was calculated as deviation from the control line performance by equation given by Hill (1972) as follows :

\section{Where :}

$$
\Delta \mathbf{G}=\left(\mathbf{S}_{\mathrm{t}}-\mathbf{C}_{\mathrm{t}}\right)
$$

$S$ and $C$ are the means of selected and control lines in generation number $(t)$.

Realized genetic correlation estimated according to the following formula given by Becker (1980) :

$$
\underset{\text { Where : }}{\mathbf{r}_{\mathrm{G} 1 \mathrm{G} 2}}=\frac{\Delta \mathrm{G}_{1}}{\Delta \mathrm{G}_{2}} \cdot \frac{\sigma_{\mathrm{A} 2}}{\sigma_{\mathrm{A} 1}}
$$

$r_{\mathrm{G} 1 \mathrm{G} 2}=$ realized genetic correlation .

$\Delta \mathbf{G}_{1}=$ Selection response in correlated trait.

$\Delta \mathbf{G}_{\mathbf{2}}=$ selection response in selected trait.

$\sigma_{\mathrm{A} 2}=$ additive genetic standard deviation for the selected trait.

$\sigma_{\mathrm{A} 1}=$ additive genetic standard deviation for the correlated trait.

Rate of increasing of inbreeding per generation was calculated according to Falconer (1960) by the following formula :

$$
\Delta \mathbf{F}=\frac{1}{2 \mathrm{Ne}}
$$

where $\mathrm{Ne}=\frac{4 \mathrm{FM}}{\mathrm{M}+\mathrm{F}}$

$\Delta F=$ Rate of increasing of inbreeding per generation.

$\mathrm{Ne}=$ Effective Number of population .

$\mathbf{N}=$ Real population size.

$F=$ number of females.

$M=$ number of males.

\section{RESULTES AND DISCUSSIONS}

Selected trait:

According to Model 1, the general effects of generations and lines were estimated. Table (3) presents analysis of variance of the selected trait (protein efficiency $\mathrm{g}$ protein/g egg). The effect of generations and lines were highly significant.

Similar significant effects of generations and lines were noticed by Soltan (1984). Therefore, control lines was very important to expunction the effect of each generation Hill (1979).

Table (4) illustrates that the average protein efficiencies were $0.770 \pm 0.159$, $1.001 \pm 0.452$ and $0.670 \pm 0.171$ in the first, second and third generations, respectively. The corresponding values in the control line were $0.851 \pm 0.116$, $1.133 \pm 0.250$ and $1.198 \pm 0.179$ in the 1,2 and 3 generations, respectively.

The results indicated that little increase for protein efficiency in the second generation in the selected and control lines. This may be due to the quality of diet in this generation according to the manufactory. Similar trends were noticed by Horani (1985).

However, the actual genetic responses to selection for protein efficiency were obtained in Table (5). The selection responses were $-0.081,-0.132$ and $-0.528(\mathrm{~g})$ in the first, second and third generations (Fig. 2).

The rate of breeding per generation was equal to $0.8 \%$ and it was $2.4 \%$ in the 
third generation (according to Falconer, 1960, formula).

These values means that for the selection line, we need to $670(\mathrm{~g})$ protein to produce 1 kilogram eggs. While, in control line, $1 \mathrm{~kg}$ egg need to 1198 (g) protein. So, $\mathbf{5 2 8 \mathrm { g }}$ were decreased to produce $1 \mathrm{~kg}$ eggs in each generation. Soltan (1984) reported $\Delta \mathbf{G}=-0.069$ or $12.18 \%$ from the control line. The rate of improvement in the 3 generations were $9 \%, 11 \%$ and $55 \%$, respectively. The average genetic response per generation was $25 \%$ from the control line. This higher genetic improvement per generation may be due to the primitive genetic structure of the Sinai strain as local strain.

The calculated heritability for protein efficiency $\mathrm{g}$ protein per $1 \mathrm{~g}$ eggs was 0.12 (Table 6). This was in agreement with that obtained by Guill and Washburn (1974), Heil and Pirchner (1979) and Soltan (1984).

Also, Fisher (1967) showed that the utilization of dietary protein for egg production much less efficiency in birds at the end of the laying year. Therefore, more gain could be realized in the first $\mathbf{9 0}$ days of laying.

Table (3): Analysis of variance of selected trait of Sinai chicken.

\begin{tabular}{|l|c|c|}
\hline Source of variance & DF & g P/g egg \\
\hline Bet. Sires & 33 & $0.0199^{* *}$ \\
\hline Bet. Dams/Sire & 171 & $0.0056^{* *}$ \\
\hline Generation & 2 & $0.0331^{* *}$ \\
\hline Line & 1 & $0.0248^{* *}$ \\
\hline Residual & 138 & 0.0040 \\
\hline \multicolumn{2}{|c|}{ General Mean \pm SD } & $0.937 \pm 0.22$ \\
\hline
\end{tabular}

Table (4): Means \pm S.E. of selected trait during test period in the three generations.

\begin{tabular}{|c|c|c|}
\hline \multirow{2}{*}{1} & Line & g Plg egg \\
\hline \multirow{2}{*}{2} & s & $0.770 \pm 0.15$ \\
\cline { 2 - 3 } & c & $0.851 \pm 0.11$ \\
\hline \multirow{2}{*}{3} & s & $1.001 \pm 0.45$ \\
\cline { 2 - 3 } & c & $1.133 \pm 0.25$ \\
\hline \multirow{2}{*}{3} & s & $0.670 \pm 0.17$ \\
\cline { 2 - 3 } & c & $1.198 \pm 0.17$ \\
\hline
\end{tabular}


M.E. Soltan, et al.,

Table (5): The actual genetic gain of selected trait during test period in the three generations.

\begin{tabular}{|c|c|c|c|}
\hline \multirow{2}{*}{ Trait } & \multicolumn{3}{|c|}{$\Delta \mathbf{G}$} \\
\cline { 2 - 4 } & G1 & G2 & G3 \\
\hline \multirow{2}{*}{ g Plg egg } & -0.081 & -0.132 & -0.528 \\
\hline
\end{tabular}

Table (6): Variances component estimates of the selected trait (g P/g. egg) of Sinai chickens.

\begin{tabular}{|c|c|c|c|}
\hline Trait & $\sigma^{2 \mathrm{P}}$ & $\mathrm{h}^{2}$ & $\sigma^{2 \mathrm{~A}}$ \\
\hline g P/g egg & 0.086 & 0.12 & 0.011 \\
\hline
\end{tabular}

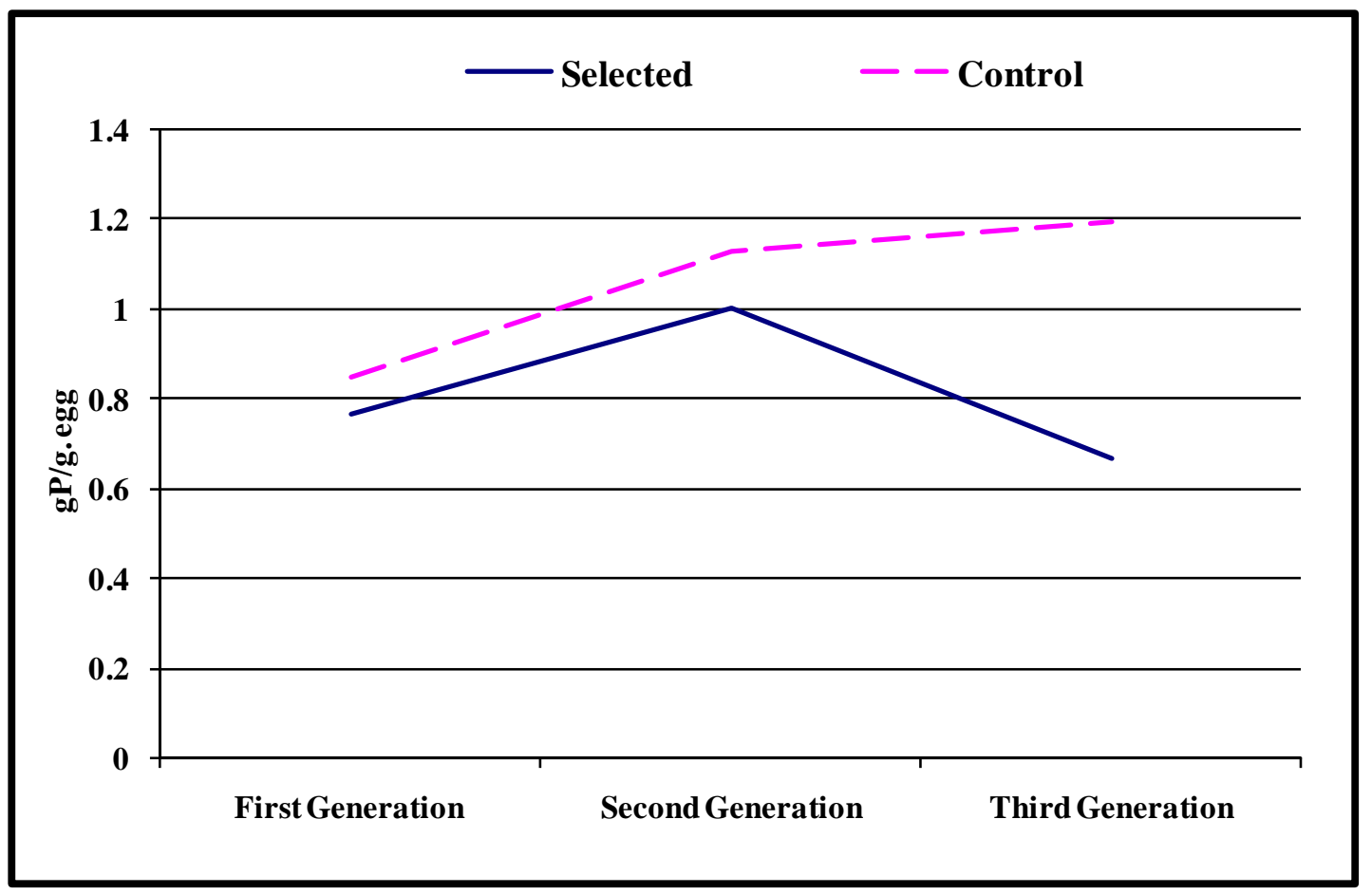

Fig (2): Protein efficiency of egg production among 3 generations.

\section{Conclusion:}

1- Protein efficiency was genetically improved by direct selection.

2- The genetic potential of local breeds or strains has not been fully studied. Improvement in management will allow specific characteristics still favored in traditional production.

\section{REFERENCES}

Becker, W.A. (1980). Manual of Quantitative Genetics. Washington state Univ.

Falconer, D.S. (1960). Introduction to quantitative genetics Oliver and Boyd, London.

Fisher, C. (1967). Factors affecting protein requirements in protein 
utilization. Oliver Boyd, Edinturgh and London.

Grasenack, H. (1981). Geflugl produktion. Deutcher Landwirtschaftsverkag (VEB), (98).

Guill, R.A. and K.W. Washburn (1974). Genetic changes efficiency of feed utilization of chicks maintaining body weight constants. Poult. Sci., 53 : 1146 $-1154$.

Heil G. and F. Pirchner, (1979). Selection on feed efficiency in lay hens direct and correlated response. $30^{\text {th }}$ Annual meeting of the European association for animal production. Harrogate.

Hill W.G. (1972). Estimation of genetic change. 2. Experimental evaluation of control population. Anim. Br. Abstr. 40 : 193 - 213.

Hill W. G. (1979). Design of quantitative genetic selection experiments.
Selection experiments in laboratory and domestic animals. The Proceeding of Symposium, 1-13.

Horani, F.G. (1985). Most severe problems in poultry feeding in Saudi Arabia. $2^{\text {nd }}$ International DLGSymposium 16-19 June. Fed. Rep. of Germany.

Seeman M., J. Gerlach and R. Dolushitz, (1983) Rentabilitat der verkangerten mast. DGS, Sonderdruck aus den Nrm. 18, 19 und 20, 9-14.

SAS (2002). SASISTAT. Statistical analysis systems for Windows. Release 9.1. SAS Institute Inc; Cary, NC, USA.

Soltan M.E. (1984). Selection of protein efficiency in Quail. Thesis Ph.D., Hohenheim Univ., West Germany.

$$
\begin{aligned}
& \text { استجابة الاتتخاب المباشر للكفاعة الغذائية للبروتين لإنتاج البيض في دجاج بدو سيناء } \\
& \text { كحمد السيد سلطان(1)، أحمد عبد الوهاب عنب(1)، أ.د. جمال عبد الستار زناتي(1)، } \\
& \text { عصام عاطف مرسي (2) عاب عند } \\
& \text { (1) قسم انتاج الدواجن، كلية الزراعة، جامعة المنوفية }
\end{aligned}
$$

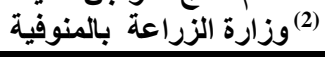

$$
\begin{aligned}
& \text { الملخص العربي }
\end{aligned}
$$




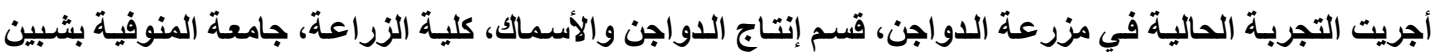

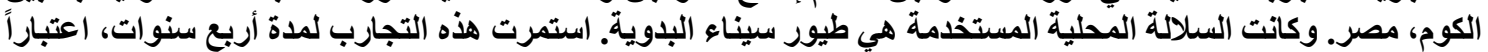

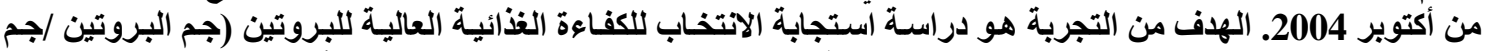
بيض) لاجاج سيناء البياض. تم حساب الكفاءة الغذائية للبروتين لإنتاج البيض خلال 90 يومًا الأولي من الإنتاج كما يلي:

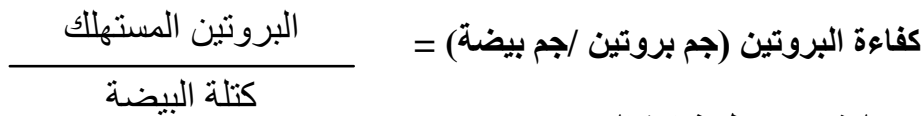

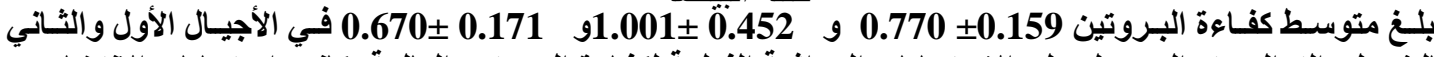

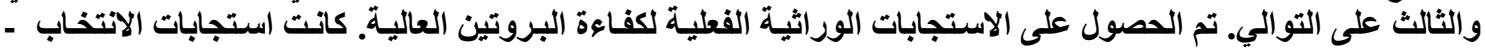

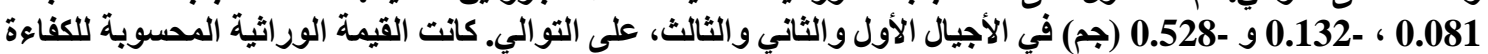
الغذائية للبروتين جم بروتين لكل 1جم من البيض (0.12).

أسماء السادة المحكمين

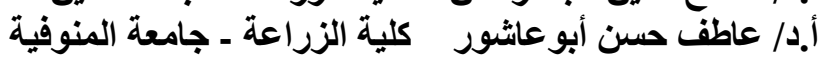

